\title{
Mercury in traditionally foraged species of fungi (macromycetes) from the karst area across Yunnan province in China
}

\author{
Jerzy Falandysz ${ }^{1,2,3} \cdot$ Małgorzata Mędyk $^{1} \cdot$ Martyna Saba $^{1} \cdot$ Ji Zhang $^{3} \cdot$ Yuanzhong Wang ${ }^{3} \cdot$ Tao $^{4}{ }^{4}$
}

Received: 12 May 2020 / Revised: 17 August 2020 / Accepted: 1 September 2020 / Published online: 21 September 2020

(C) The Author(s) 2020

\begin{abstract}
The objective of this study is to better quantify the occurrence, intake, and potential risk from $\mathrm{Hg}$ in fungi traditionally foraged in SW China. The concentrations and intakes of $\mathrm{Hg}$ were measured from 42 species including a "hard" flesh type polypore fungi and a" soft" flesh type edible species that are used in traditional herbal medicine, collected during the period 2011-2017. Three profiles of forest topsoil from the Zhenyuan site in 2015 and Changning and Dulong sites in 2016 were also investigated. The concentrations of $\mathrm{Hg}$ in composite samples of polypore fungi were usually below $0.1 \mathrm{mg} \mathrm{kg}^{-1}$ dry weight (dw) but higher levels, $0.11 \pm 0.01$ and $0.24 \pm 0.00 \mathrm{mg} \mathrm{kg}^{-1} \mathrm{dw}$, were noted in Ganoderma applanatum and Amauroderma niger respectively, both from the Nujiang site near the town of Lanping in NW Yunnan. Hg concentrations in Boletaceae species were usually well above $1.0 \mathrm{mg} \mathrm{kg}^{-1} \mathrm{dw}$ and as high as $10 \mathrm{mg} \mathrm{kg}^{-1} \mathrm{dw}$. The quality of the mushrooms in this study in view of contamination with $\mathrm{Hg}$ showed a complex picture. The "worst case" estimations showed probable intake of $\mathrm{Hg}$ from $0.006 \mu \mathrm{g} \mathrm{kg}^{-1}$ body mass (bm) ("hard" type flesh) to $0.25 \mu \mathrm{g} \mathrm{kg}^{-1} \mathrm{bm}$ ("soft" flesh) on a daily basis for capsulated products, from 17 to $83 \mu \mathrm{g} \mathrm{kg}{ }^{-1} \mathrm{bm}$ ("soft" flesh) in a meal ("hard" type flesh mushrooms are not cooked while used in traditional herbal medicine after processing), and from 0.042 to 1.7 and 120 to $580 \mu \mathrm{g} \mathrm{kg}^{-1}$ bm on a weekly basis, respectively.
\end{abstract}

\section{Key points}

- Polypore species were slightly contaminated with $\mathrm{Hg}$.

- Hg maximal content in the polypore was $<0.25 \mathrm{mg} \mathrm{kg}^{-1}$ dry weight.

- Many species from Boletaceae family in Yunnan showed elevated Hg.

- Locals who often eat Boletus may take Hg at a dose above the daily reference dose.

Keywords Ethnobotany $\cdot$ Forest soil $\cdot$ Functional foods $\cdot$ Ganoderma $\mathrm{spp} . \cdot$ Traditional Asian medicines $\cdot$ Wild foods

Jerzy Falandysz is a visiting professor at the affiliations 2 and 3.

Dedication

This manuscript is dedicated to the memory of Dr. Tjakko Stijve (19372020).

Jerzy Falandysz

jerzy.falandysz@ug.edu.pl; jerzy.falandysz@gmail.com

1 Environmental Chemistry and Ecotoxicology, University of Gdańsk, 80-308 Gdańsk, Poland

2 Environmental and Computational Chemistry Group, School of Pharmaceutical Sciences, Zaragocilla Campus, University of Cartagena, Cartagena 130015, Colombia

3 Yunnan Academy of Agricultural Sciences, Medicinal Plants Research Institute, Kunming 650200, Yunnan, China

4 Yuxi Normal University, School of Chemical Biology and Environment, Yuxi 653100, Yunnan, China

\section{Introduction}

Mushrooms (Macromycetes), dried and powdered or in the form of extracts, are traditionally popular in Chinese herbal medicine and elsewhere in Asia and are also considered functional foods (Bhatt et al. 2018; Wang et al. 2013; Wasser 2010). This traditional use of wild mushrooms as medicines has survived in other parts of the world, including Mexico (Nnorom et al. 2019; Santiago et al. 2016; Yongabi 2019). In the past, mushrooms were also used in folk medicine in Europe but this tradition has practically disappeared there (Gründemann et al. 2020; Grzywnowicz 2001, 2007). However, scientific evidence supporting the use of mushrooms in the treatment of disease is questioned or considered premature (Money 2016). Traditionally 
foraged edible species of fungi are valued in traditional herbal medicines largely due to active organic compounds and an example can be species from the genus Fomitopsis and Ganoderma, while much less is information on minerals and heavy metal contaminants (Bhatt et al. 2018; Nnorom et al. 2013; Zaidman et al. 2005).

Data shows that many mushrooms are vulnerable to contamination with mercury $(\mathrm{Hg})$ compounds that are absorbed by the mycelia of the fungi and efficiently bioconcentrated in fruiting bodies both from the field and controlled experimental studies (Bressa et al. 1988; Crane et al. 2010; Falandysz et al. 2007). This characteristic has been associated to species-specific genetic features in connection to soil bedrock geochemical anomalies and anthropogenic pollution (Falandysz 2016; Melgar et al. 2009; Nasr and Arp 2011). The genetic, species-specific susceptibility of fungi to accumulation of $\mathrm{Hg}$ and their vulnerability to contamination with this element can be explained in part by the type and quantity of sulfur (S) and also selenium ( $\mathrm{Se}$ )-containing ligands that they produce (Kavčič et al. 2018, 2019; Nasr et al. 2012). Mushrooms found in different regions of China can be substantially contaminated with geogenic $\mathrm{Hg}$ absorbed from background soil from the mineral belt (Falandysz et al. 2015b). Continental Asia, and also some other continents, have areas with bedrock and soils enriched in mercury that occurs largely in the mineral, cinnabar $(\mathrm{HgS})$, from the vast region of the Circum-Pacific Mercuriferous Belt (Gustin et al. 1999). Cinnabar mining at the Lanmuchang site in Gùizhōu in southwestern China, and the use of $\mathrm{HgS}$ as red pigment vermilion and as a sedative in traditional herbal medicine, has an over 2000-year-old history in China (Wang 1944; Young et al. 2002).

Geogenic $\mathrm{Hg}$ is well dispersed on the land and oceans and due to degassing is subject to a specific global biogeochemical circulation (Ariya et al. 2015; Falandysz et al. 2020d). Regions with a mineral belt can be abundant not only in $\mathrm{HgS}$, but also in ores bearing other elements such as $\mathrm{As}, \mathrm{F}, \mathrm{Pb}, \mathrm{Ag}, \mathrm{Mo}, \mathrm{Ni}, \mathrm{Au}, \mathrm{Re}, \mathrm{Se}$, $\mathrm{V}$, and $\mathrm{Zn}$. The occurrence of $\mathrm{Hg}$ is also associated with anthropogenic activities such as copper-bearing shales (Kijewski 1989). Forest soils can act as a long-term sink of airborne $\mathrm{Hg}$ from anthropogenic emissions due to ongoing use of $\mathrm{Hg}$ and its compounds, legacy sources, gold mining, combustion of fossil fuels, and thermal processes and China is the major emitter of $\mathrm{Hg}$ from anthropogenic sources at both the regional and global scales (Chen et al. 2019; Suchara and Sucharova 2002).

Elevated and occasionally high concentrations of $\mathrm{Hg}$ in forest topsoils in several remote and rural areas in the Yunnan province in China strongly indicate the overriding role of geogenic sources of $\mathrm{Hg}$ in local mushrooms, but anthropogenic pollution in the forest topsoil is a source (in the $0-10$-cm layer of soil in Dayingjie in Yuxi up to $3.4 \mathrm{mg} \mathrm{kg}^{-1}$ $\mathrm{dw}$ ) that cannot be neglected (Falandysz et al. 2015b). The organic layer of soil in forests efficiently retains airborne $\mathrm{Hg}$ from direct deposition, trough fall, and litter fall, and this makes a significant contribution to its absorption by mycelia and accumulation in the flesh of fruiting bodies (Demers et al. 2007; Falandysz et al. 2014). Mycelia are able to colonize and take up minerals from relatively large volumes of soil substrate including different layers of the soil horizon in which they grow. Some mushroom species also produce rhizomorphs and mycelial cords, which act as organs of absorption and translation of nutrients and water absorption and translocation, and colonization of substrates (Yafetto 2018). Therefore, the elemental contaminants contained in the mushroom's fruiting bodies - regardless of the uptake, translocation, and accumulation mechanisms or competition between the elements - present an integral picture of the local environmental conditions in view of the physiology and adaptiveness of a particular species.

The Yunnan is home to a biological diversity of fungi species that grow within a vast mountainous terrain (Yunnan has area of 394,000 sq. km and the average elevation is $1980 \mathrm{~m}$ and a highest point has $6740 \mathrm{~m}$ a.s.l. at Kawagebo) that is characterized by canyons and large rivers $(\mathrm{Nu}$, Yangzi, and Mekong rivers), as well as areas of polymetallic soils that are naturally enriched in As and $\mathrm{Hg}$, and other hazardous elements to combined diversity in species and terrains present a challenge to the study of the local fungi (Li and Wang 2008; Wen and Chi 2007).

Additionally, knowledge and data on the occurrence of $\mathrm{Hg}$ in mushrooms that are popular in Chinese medicine are largely absent. Mercury and its compounds are highly toxic and especially relevant in foods including edible mushrooms is their contamination with neurotoxic monomethylmercury (MeHg) (Fernandes et al. 2020; WHO 2011; Stijve and Roschnik 1974). It has to be emphasized that wild-growing mushrooms efficiently bioconcentrate $\mathrm{Hg}$ from soil currently contaminated with this element both due to geological processes and from anthropogenic depositions (Falandysz 2002, 2016; Kavčič et al. 2019; Nasr and Arp 2011; Saba et al. 2016a). In result, and due to high capacity of mushrooms to accumulate $\mathrm{Hg}$, the edible wild-growing species accumulate the largest amount of $\mathrm{Hg}$ (Falandysz et al. 2015b; Melgar et al. 2009).

The current study addresses this knowledge gap by investigating the fruiting bodies of 42 commercially important species of mushrooms from 23 sites in the Province of Yunnan collected during the period, 2011-2017 (Fig. 1). The collection sites were usually located in regions were mushrooms from the wild are intensively foraged, along with places where local markets for mushrooms exist. In parallel, samples of topsoil layers from three different forested locations spatially distantly distributed across the province (Figs. 1 and 2) were also collected in order to get some information on the $\mathrm{Hg}$ content in the soil substrata in Yunnan. 
Fig. 1 Localization of the sampling sites of mushrooms and topsoil from Yunnan

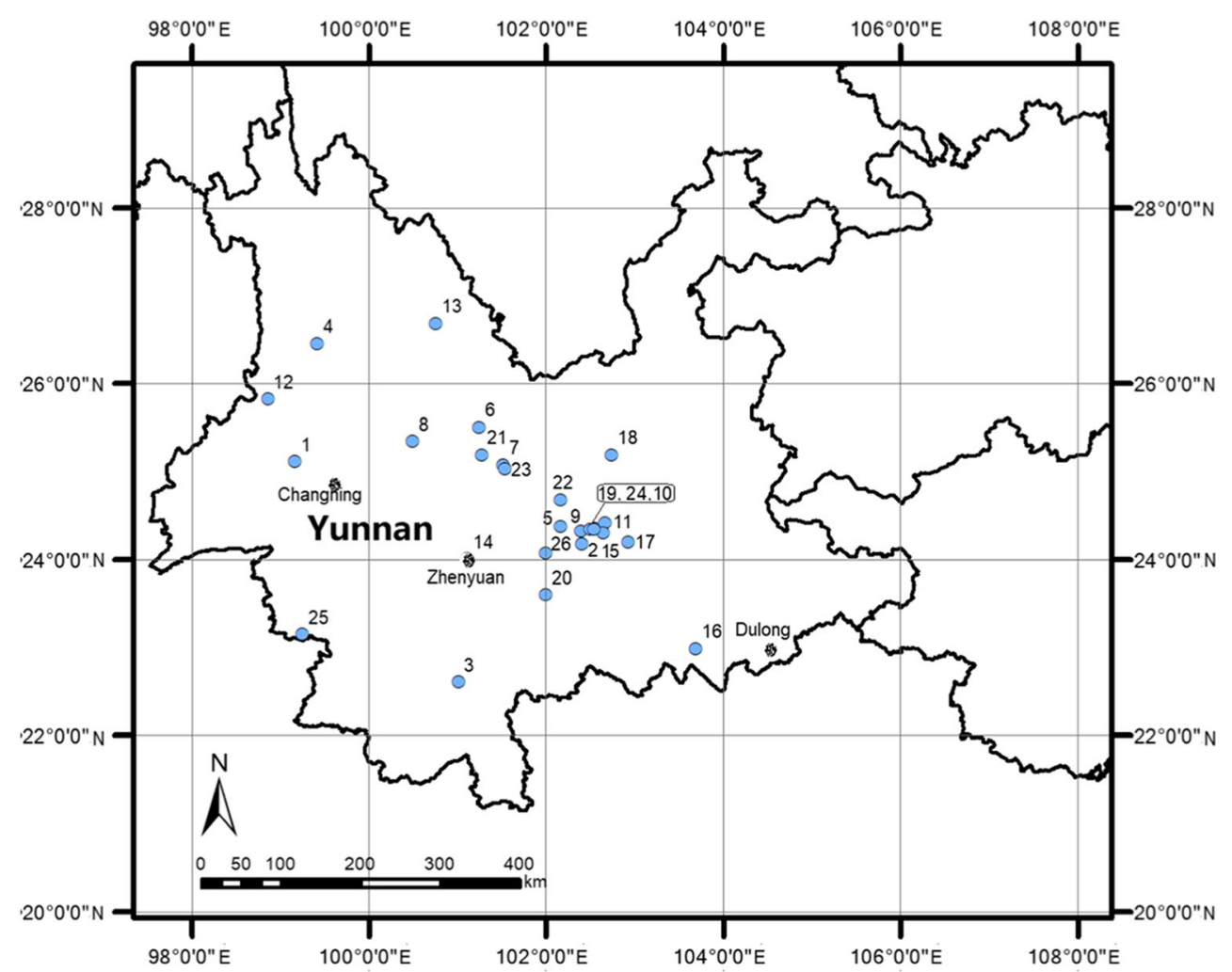

\section{Materials and methods}

\section{Forest topsoil}

Forest topsoil layers were collected in 2015 from undisturbed rural locations in Yunnan, at the Zhenyuan site (coordinates: $24^{\circ} 26^{\prime} 45^{\prime \prime} \mathrm{N}$ and $\left.100^{\circ} 33^{\prime} 36^{\prime \prime} \mathrm{E}\right)$ at Mt. Ailao in the Pu'er prefecture at an altitude of circa $1400 \mathrm{~m}$ above sea level, from the Changning site $\left(24^{\circ} 43^{\prime} 44^{\prime \prime} \mathrm{N}\right.$ and $\left.99^{\circ} 45^{\prime} 4^{\prime \prime} \mathrm{E}\right)$ at an altitude of $1950 \mathrm{~m}$ a.s.l., and from the Dulong site $\left(22^{\circ} 53^{\prime} 21^{\prime \prime} \mathrm{N}\right.$ and $104^{\circ} 32^{\prime} 52^{\prime \prime}$ E) at an altitude of $915 \mathrm{~m}$ a.s.l. in 2016 (Figs. 1 and 2).

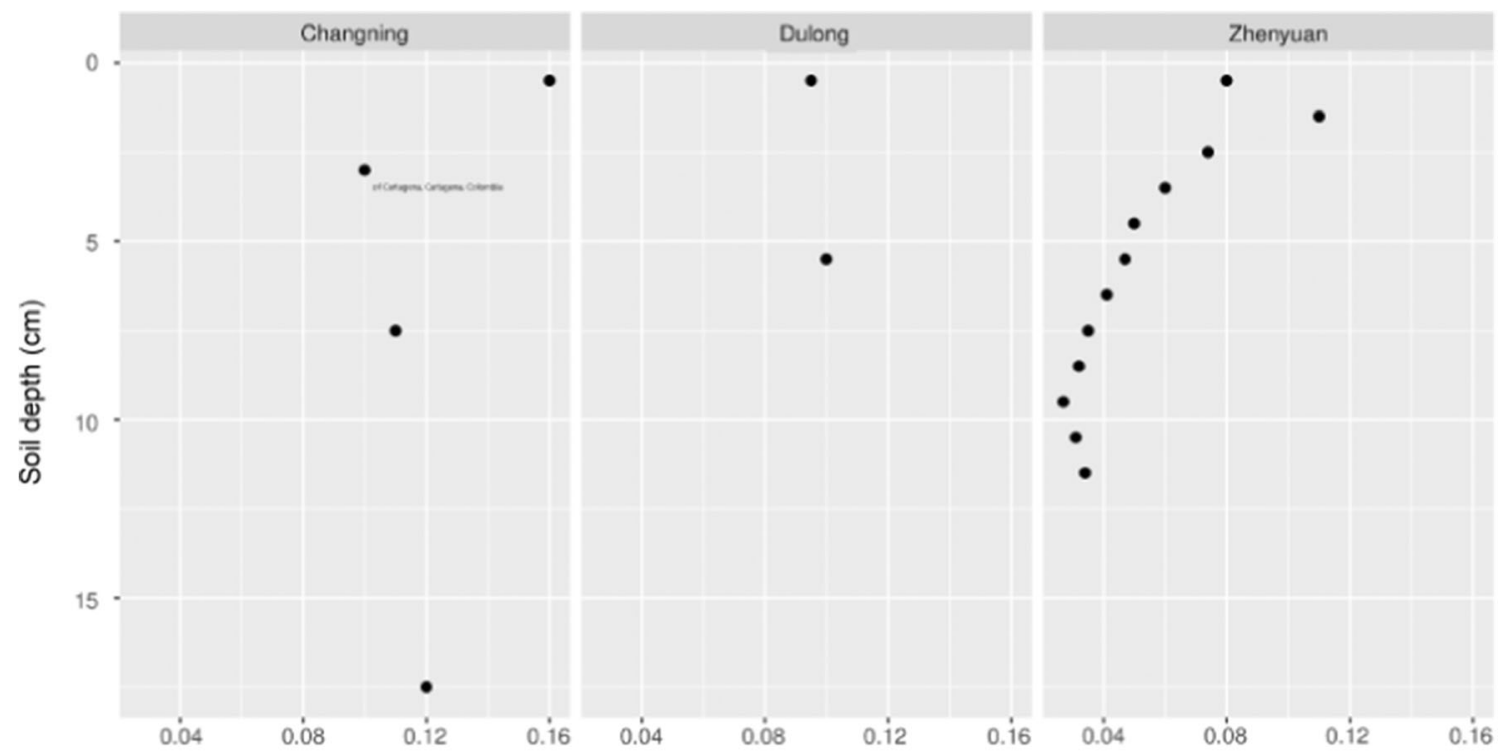

$\mathrm{Hg}$ content $(\mathrm{mg} / \mathrm{kg})$

Fig. 2 Mercury concentration ( $\mathrm{Hg} \mathrm{mg} \mathrm{kg}^{-1} \mathrm{dw}$ ) profiles of the forest soil cores taken from Changning, Dulong, and Zhenyuan-Pu'er in the Yunnan province 
The soil layers at the sites were taken from different depth (Fig. 2) using a stainless steel slicer after the soil horizon was uncovered. Litter covering soil surface was removed before sampling. The sections of soil horizons sampled weighed circa $100 \mathrm{~g}$ each. If necessary, soils were freed from visible plant roots on site, and placed into brand new sealed polyethylene bags. At the laboratory, samples were air dried at room temperature for 8-10 weeks under dry and clean conditions to obtain aerially dry material. Dried soils were powdered in a porcelain mortar, sieved through a pore size of a 2-mm plastic sieve (a plastic sieve each time washed, well rinsed with deionized water, and dried before re-use), transferred into brand new sealed polyethylene bags, and kept until analysis for up to 1 week in tightly closed plastic containers under dry condition.

\section{Fungi}

The wild mushroom species included genera such as Baorangia, Boletus, Butyriboletus, Caloboletus, Catathelasma, Fomes, Fomitopsis, Ganoderma, Ischnoderma, Lactarius, Leccinum, Lentinus, Neoboletus, Retiboletus, Rubroboletus, Suillellus, Suillus, Sutorius, Thelephora, Tylopilus, Tyromyces, and Xerocomus sp. In total, 42 species of medicinal edible fungi were collected, including: Agaricus blazei Murrill, Baorangia bicolor (Kuntze) G. Wu, Halling \& Zhu L. Yang, Boletus auripes Peck, Boletus bainiugan Dentinger, Boletus calopus (Pers.) Vizzini, Boletus speciosus Frost, Boletus tomentipes Earle, Butyriboletus regius (Krombh.) D. Arora \& J.L. Frank, Butyriboletus subsplendidus (W.F. Chiu) Kuan Zhao, G. Wu \& Zhu L. Yang, Caloboletus calopus (Pers.) Vizzini, Catathelasma ventricosum (Peck) Singer, Fomes rufolaccatus Lloyd, Fomitopsis pinicola (Swartz.:Fr), Fomitopsis ulmaria (Sor.:Fr.) Bond. et Sing., Ganoderma applanatum (Pers.) Pat, Ganoderma capense (Lloyd) Teng, Ganoderma japonicum (Fr.) Lloyd, Ganoderma kunmingense Zhao, Ganoderma lingzhi Sheng H.Wu, Y.C.Dai \& Y.Cao, Ganoderma lucidum (Leyss. ex Fr.), Ganoderma luteomarginatum Zhao, Xu et Zhang, Ganoderma philippii (Bres. \& Henn. ex Sacc.) Bres, Ganoderma ramosissimum Zhao, Ganoderma sinense Zhao, Xu et Zhang, Ganoderma tsugae Murr, Ischnoderma resinosum (Schaeff.: Fr.) Karst., Lactarius deliciosus (L.) Gray, Leccinum extremiorientale (Lj.N. Vassiljeva) G. Wu \& Zhu L. Yang, Lentinula edodes (Berk.) Pegler, Neoboletus brunneissimus (W.F. Chiu) G. Wu \& Zhu L. Yang, Retiboletus griseus (Frost) Manfr. Binder \& Bresinsky, Retiboletus ornatipes (Peck) Manfr. Binder \& Bresinsky, Rubroboletus sinicus (W.F. Chiu) Kuan Zhao \& Zhu L. Yang, Suillellus luridus (Schaeff.) Murrill, Suillus bovinus (L.) Roussel, Sutorius magnificus (W.F. Chiu) G. $\mathrm{Wu} \&$ Zhu L. Yang, Thelephora ganbajun Zang, Tylopilus chromapes (Frost) A.H. Sm. \& Thiers, Tylopilus felleus (Bull.:Fr.) Karst, Tyromyces albidus (Schaeff ex Secr.)
Donk, and Xerocomus sp. The composite samples $(n>1)$ contained up to 100 individual fruiting bodies per species (Table 1) and location (Fig. 1).

At collection sites, mushrooms were cleaned from any visible foreign matter using a ceramic knife and a plastic brush. For some species, the whole fruiting bodies were used and for others, each individual fruiting body was separated into cap and stipe, and the individual samples were pooled accordingly (Table 1). The fungal materials were dried at $65^{\circ} \mathrm{C}$ to constant mass (Ultra FD1000 dehydrator, Ezidri, Australia) (Kojta et al. 2015). The dried, fungal materials were ground in a porcelain mortar to a fine powder, passed through an 80mesh sieve and stored in a screw-sealed plastic (low-density polyethylene) bags under dry conditions.

\section{Determination of $\mathrm{Hg}$}

The analytical methodology for $\mathrm{Hg}$ determination in fungal and soil materials has been presented in detail before but a summarized description is given below (Jarzyńska and Falandysz 2011; Saba et al. 2016c). Double distilled water was used for the preparation of the solutions. A mercury standard solution of $1.0 \mathrm{mg} \mathrm{Hg} \mathrm{mL}^{-1}$ was obtained from the $10 \mathrm{mg} \mathrm{mL}^{-1}$ standard stock solution (Merck). Blanks and 25, 50, 100, 150, and $200 \mu \mathrm{L}$ (high mode) and 3, 5, 10, 15, and $20 \mu \mathrm{L}$ (low mode) of $1.0 \mathrm{mg} \mathrm{mL}^{-1} \mathrm{Hg}$ standard solutions were injected into the $\mathrm{Hg}$ analyzers for the construction of calibration curves.

The determinations of $\mathrm{Hg}$ content were performed using cold-vapor atomic absorption spectroscopy (CV-AAS) by direct sample thermal decomposition coupled with gold wool trap and amalgamation of $\mathrm{Hg}$ vapor and $\mathrm{Hg}$ desorption and quantitative measurement at a wavelength of $253.7 \mathrm{~nm}$. The instruments used were the MA-2000 mercury analyzers (Nippon Instruments Corporation, Takatsuki, Japan), both, with and without auto sampler and operated respectively in high ( 25 to $150 \mathrm{ng} \mathrm{Hg}$ per sample) and low (3 to $20 \mathrm{ng} \mathrm{Hg}$ per sample) modes (Jarzyńska and Falandysz 2011).

Quality assurance and quality control measures included the analysis of procedural blanks and certified reference materials as described before (Falandysz et al. 2015b; Jarzyńska and Falandysz 2011; Saba et al. 2016c). Two certified reference materials were analyzed: CS-M-2 (dried Agaricus campestris) with declared concentration of $\mathrm{Hg}$ at $0.164 \pm$ $0.004 \mathrm{mg} \mathrm{kg}^{-1}$ and determined concentration of $\mathrm{Hg}$ at 0.16 $\pm 0.01 \mathrm{mg} \mathrm{kg}^{-1}(n=8$; recovery 98\%), and CS-M-3 (dried Boletus edulis) with declared concentration of $\mathrm{Hg}$ at $2.849 \pm$ $0.104 \mathrm{mg} \mathrm{kg}^{-1}$ and determined concentration of $\mathrm{Hg}$ at $2.8 \pm$ $0.0 \mathrm{mg} \mathrm{kg}^{-1}(n=5$; recovery $98 \%)$. The number of replicates was 2-3 for the material with relatively high $\mathrm{Hg}$ content, while 2-4 for the material with relatively low $\mathrm{Hg}$ content. Two blank samples were included with each sample studied and four subsamples of certified reference materials were analyzed with each set of 8 real samples. 
Table 1 Contents of $\mathrm{Hg}\left(\mathrm{mg} \mathrm{kg}^{-1}\right.$ dry weight; arithmetic mean and standard deviation) in the wild-growing and cultivated medicinal mushrooms from China

\begin{tabular}{|c|c|c|c|c|c|}
\hline \multirow[t]{2}{*}{ Species and year } & \multirow[t]{2}{*}{ Sampling site } & \multicolumn{3}{|l|}{$\mathrm{Hg}$} & \multirow[t]{2}{*}{$Q_{\mathrm{C} / \mathrm{s}}$} \\
\hline & & Caps & Stipes & Whole fruiting bodies ${ }^{\mathrm{b}}$ & \\
\hline Agaricus blazei (100) ${ }^{* \mathrm{a}} 2015$ & Longyang, Baoshan $\left[1^{\#}\right]$ & $0.085 \pm 0.001$ & $0.042 \pm 0.001$ & 0.064 & 2.0 \\
\hline Amauroderma bataanense (15) 2014 & Eshan, Yuxi [2] & $0.065 \pm 0.001$ & $0.041 \pm 0.001$ & WD & 1.6 \\
\hline Amauroderma guangxiense (/) 2011 & Laiyanghe, Pu'er [3] & WD & WD & $0.041 \pm 0.001$ & WD \\
\hline Amauroderma niger (/) 2012 & Lanping, Nujiang [4] & WD & WD & $0.24 \pm 0.00$ & WD \\
\hline Baorangia bicolor (56) 2017 & Tadian, Yuxi [5] & $3.1 \pm 0.1$ & $1.3 \pm 0.0$ & 2.2 & 2.4 \\
\hline Baorangia bicolor (13) 2017 & Yaoan, Chuxiong [6] & $5.0 \pm 0.0$ & $2.7 \pm 0.0$ & 3.9 & 1.8 \\
\hline Baorangia bicolor (5) 2017 & Donggua, Chuxiong [7] & $2.8 \pm 0.1$ & $1.3 \pm 0.1$ & 2.1 & 2.1 \\
\hline Baorangia bicolor (9) 2017 & Midu, Dali [8] & $0.76 \pm 0.04$ & $0.37 \pm 0.02$ & 0.57 & 2.0 \\
\hline Baorangia bicolor (22) 2017 & Luohe, Yuxi [9] & $8.6 \pm 0.4$ & $3.6 \pm 0.2$ & 6.1 & 2.4 \\
\hline Baorangia bicolor (5) 2017 & Donggua, Chuxiong [7] & $2.8 \pm 0.1$ & $1.3 \pm 0.1$ & 2.1 & 2.1 \\
\hline Baorangia bicolor (18) 2017 & Liujie, Yuxi [10] & $4.9 \pm 0.2$ & $4.3 \pm 0.2$ & 4.6 & 1.1 \\
\hline Baorangia bicolor (43) 2017 & Midu, Dali [8] & $1.5 \pm 0.1$ & $0.91 \pm 0.03$ & 1.2 & 1.6 \\
\hline Boletus auripes (12) 2017 & Tadian, Yuxi [5] & $0.93 \pm 0.02$ & $0.58 \pm 0.00$ & 0.76 & 1.6 \\
\hline Boletus bainiugan (14) 2017 & Yaoan, Chuxiong [6] & $5.6 \pm 0.2$ & $2.8 \pm 0.1$ & 4.2 & 2.0 \\
\hline Boletus bainiugan (6) 2017 & Longyang, Baoshan [1] & $6.1 \pm 0.3$ & $2.1 \pm 0.1$ & 4.1 & 2.9 \\
\hline Boletus bainiugan (22) 2017 & Donggua, Chuxiong [7] & $14 \pm 0$ & $6.0 \pm 0.2$ & 10 & 2.3 \\
\hline Boletus bainiugan (11) 2017 & Longyang, Baoshan [1] & $11 \pm 0$ & $4.8 \pm 0.0$ & 7.9 & 2.3 \\
\hline Boletus bainiugan (18) 2017 & Midu, Dali [8] & $1.0 \pm 0.0$ & $0.64 \pm 0.03$ & 0.82 & 1.6 \\
\hline Boletus speciosus (23) 2017 & Longyang, Baoshan [1] & $5.3 \pm 0.2$ & $3.2 \pm 0.1$ & 4.3 & 1.7 \\
\hline Boletus speciosus (2) 2017 & Tadian, Yuxi [5] & $2.3 \pm 0.1$ & $1.5 \pm 0.0$ & 1.9 & 1.5 \\
\hline Boletus speciosus (273) 2017 & Longyang, Baoshan [1] & $6.4 \pm 0.1$ & $4.0 \pm 0.1$ & 5.2 & 1.6 \\
\hline Boletus speciosus (15) 2017 & Liujie, Yuxi [10] & $4.8 \pm 0.0$ & $1.6 \pm 0.1$ & 3.2 & 3.0 \\
\hline Boletus speciosus (12) 2017 & Luohe, Yuxi [9] & $5.4 \pm 0.3$ & $3.6 \pm 0.1$ & 4.5 & 1.5 \\
\hline Boletus tomentipes (21) 2017 & Liujie, Yuxi [10] & $5.6 \pm 0.1$ & $1.1 \pm 0.4$ & 3.4 & 5.1 \\
\hline Butyriboletus regius (9) 2017 & Luohe, Yuxi [9] & $4.6 \pm 0.1$ & $2.3 \pm 0.1$ & 3.5 & 2.0 \\
\hline Butyriboletus subsplendidus (10) 2017 & Longyang, Baoshan [1] & $12 \pm 1$ & $5.2 \pm 0.0$ & 8.6 & 2.3 \\
\hline Caloboletus calopus (11) 2017 & Longyang, Baoshan [1] & $5.9 \pm 0.0$ & $1.7 \pm 0.1$ & 3.8 & 3.5 \\
\hline Caloboletus calopus (10) 2017 & Yaoan, Chuxiong [6] & $4.1 \pm 0.1$ & $1.1 \pm 0.0$ & 2.6 & 3.7 \\
\hline Caloboletus calopus (4) 2017 & Longyang, Baoshan [1] & $2.9 \pm 0.0$ & $1.2 \pm 0.0$ & 2.1 & 2.4 \\
\hline Caloboletus calopus (13) 2017 & Anhua, Yuxi [11] & $1.6 \pm 0.1$ & $1.1 \pm 0.0$ & 1.4 & 1.5 \\
\hline Caloboletus calopus (11) 2017 & Longyang, Baoshan [1] & $5.9 \pm 0.0$ & $1.7 \pm 0.1$ & 3.8 & 3.5 \\
\hline Caloboletus calopus (10) 2017 & Luohe, Yuxi [9] & $9.8 \pm 0.3$ & $8.4 \pm 0.0$ & 9.1 & 1.2 \\
\hline Caloboletus calopus (3) 2017 & Tadian, Yuxi [5] & $1.3 \pm 0.0$ & $0.70 \pm 0.00$ & 1.0 & 1.9 \\
\hline Catathelasma ventricosum (6) 2014 & Eshan, Yuxi [2] & $5.5 \pm 0.0$ & $1.4 \pm 0.1$ & 3.9 & 3.9 \\
\hline Fomes rufolaccatus (1) 2014 & Zhengyuan, Pu'er [14] & WD & WD & $0.069 \pm 0.001$ & WD \\
\hline Fomes rufolaccatus (1) 2014 & Jiuxi, Yuxi [15] & WD & WD & $0.12 \pm 0.00$ & WD \\
\hline Fomitopsis pinicola (1) 2014 & Lushui, Nujiang [12] & WD & WD & $0.024 \pm 0.001$ & WD \\
\hline Fomitopsis pinicola (1) 2014 & Lushui, Nujiang [12] & WD & WD & $0.027 \pm 0.000$ & WD \\
\hline Fomitopsis pinicola (1) 2014 & Yongsheng, Lijiang [13] & WD & WD & $0.035 \pm 0.002$ & WD \\
\hline Fomitopsis pinicola (1) 2014 & Lushui, Nujiang [12] & WD & WD & $0.018 \pm 0.001$ & WD \\
\hline Fomitopsis ulmaria (1) 2014 & Lanping, Nujiang [4] & WD & WD & $0.13 \pm 0.00$ & WD \\
\hline Ganoderma applanatum (/) 2012 & Lanping, Nujiang [4] & WD & WD & $0.11 \pm 0.01$ & WD \\
\hline Ganoderma capense (/) 2012 & Pingbian, Honghe [16] & WD & WD & $0.19 \pm 0.01$ & WD \\
\hline Ganoderma japonicum (10) 2014 & Huaning, Yuxi [17] & $0.088 \pm 0.002$ & $0.047 \pm 0.00$ & 0.080 & 1.9 \\
\hline Ganoderma kunmingense (15) 2012 & Xiaoshao, Kunming [18] & WD & WD & $0.012 \pm 0.002$ & WD \\
\hline Ganoderma lingzhi (8) 2013 & Xiaoshao, Kunming [18] & $0.086 \pm 0.004$ & $0.088 \pm 0.00$ & 0.087 & 0.98 \\
\hline
\end{tabular}


Table 1 (continued)

\begin{tabular}{|c|c|c|c|c|c|}
\hline \multirow[t]{2}{*}{ Species and year } & \multirow[t]{2}{*}{ Sampling site } & \multicolumn{3}{|l|}{$\mathrm{Hg}$} & \multirow[t]{2}{*}{$Q_{\mathrm{C} / \mathrm{S}}$} \\
\hline & & Caps & Stipes & Whole fruiting bodies ${ }^{\mathrm{b}}$ & \\
\hline Ganoderma lingzhi (25) 2014 & Xiaoshao, Kunming [18] & $0.10 \pm 0.00$ & $0.077 \pm 0.003$ & 0.095 & 1.3 \\
\hline Ganoderma lingzhi (17) 2015 & Xiaoshao, Kunming [18] & $0.088 \pm 0.00$ & $0.042 \pm 0.002$ & 0.079 & 2.1 \\
\hline Ganoderma lingzhi (/) 2012 & Dayingjie, Yuxi [19] & WD & WD & $0.096 \pm 0.004$ & WD \\
\hline Ganoderma lingzhi (6) 2013 & Yuanjiang, Yuxi [20] & $0.10 \pm 0.00$ & $0.081 \pm 0.004$ & 0.096 & 1.2 \\
\hline Ganoderma lingzhi (10) 2013 & Lanping, Nujiang [4] & $0.086 \pm 0.00$ & $0.053 \pm 0.002$ & 0.079 & 1.6 \\
\hline Ganoderma lucidum (7) 2012 & Huaning, Yuxi [17] & $0.085 \pm 0.001$ & $0.074 \pm 0.004$ & 0.083 & 1.1 \\
\hline Ganoderma luteomarginatum (10) 2012 & Huaning, Yuxi [17] & $0.18 \pm 0.00$ & $0.095 \pm 0.003$ & 0.16 & 1.9 \\
\hline Ganoderma philippii (10) 2011 & Laiyanghe, Pu'er [3] & WD & WD & $0.022 \pm 0.001$ & WD \\
\hline Ganoderma philippii (/) 2011 & Laiyanghe, Pu'er [3] & WD & WD & $0.033 \pm 0.001$ & WD \\
\hline Ganoderma ramosissimum (10) 2012 & Huaning, Yuxi [17] & WD & WD & $0.059 \pm 0.003$ & WD \\
\hline Ganoderma sinense (8) 2013 & Lanping, Nujiang [4] & WD & WD & $0.20 \pm 0.00$ & WD \\
\hline Ganoderma tsugae (/) 2012 & Lanping, Nujiang [4] & WD & WD & $0.085 \pm 0.002$ & WD \\
\hline Ischnoderma resinosum (1) 2014 & Nanhua, Chuxiong [21] & WD & WD & $0.060 \pm 0.000$ & WD \\
\hline Lactarius delicious (30) 2017 & Longyang, Baoshan [1] & $1.2 \pm 0.0$ & $0.83 \pm 0.04$ & 1.1 & 1.4 \\
\hline Leccinum extremiorientale (23) 2017 & Yimen, Yuxi [22] & $6.1 \pm 0.5$ & $2.2 \pm 0.1$ & 3.6 & 2.8 \\
\hline Leccinum extremiorientale (12) 2017 & Luohe, Yuxi [9] & $3.7 \pm 0.1$ & $1.2 \pm 0.0$ & 2.1 & 3.1 \\
\hline Leccinum extremiorientale (10) 2017 & Donggua, Chuxiong [7] & $3.3 \pm 0.1$ & $1.4 \pm 0.2$ & 2.1 & 2.4 \\
\hline Leccinum extremiorientale (9) 2017 & Luohe, Yuxi [9] & $3.6 \pm 0.2$ & $1.3 \pm 0.1$ & 2.1 & 2.8 \\
\hline Lentinula edodes (70) 2015 & Wuding, Chuxiong [22] & $0.039 \pm 0.002$ & $0.029 \pm 0.001$ & 0.034 & 1.3 \\
\hline Lentinula edodes (100) 2015 & Longyang, Baoshan [1] & $0.015 \pm 0.001$ & $0.015 \pm 0.001$ & 0.015 & 1.0 \\
\hline Neoboletus brunneissimus (6) 2017 & Liujie, Yuxi [10] & $2.8 \pm 0.0$ & $0.95 \pm 0.03$ & 1.9 & 2.9 \\
\hline Retiboletus griseus (46) 2017 & Zixi, Chuxiong [23] & $1.1 \pm 0.0$ & $0.72 \pm 0.01$ & 0.91 & 1.5 \\
\hline Retiboletus griseus (10) 2017 & Dayingjie, Yuxi [19] & $2.3 \pm 0.0$ & $1.4 \pm 0.1$ & 1.8 & 1.6 \\
\hline Retiboletus ornatipes (10) 2017 & Liujie, Yuxi [10] & $1.4 \pm 0.0$ & $1.5 \pm 0.1$ & 1.5 & 0.93 \\
\hline Retiboletus ornatipes (9) 2017 & Donggua, Chuxiong [7] & $2.8 \pm 0.2$ & $1.0 \pm 0.0$ & 1.9 & 2.8 \\
\hline Rubroboletus sinicus (4) 2017 & Liujie, Yuxi [10] & $2.6 \pm 0.1$ & $3.1 \pm 0.0$ & 2.9 & 0.68 \\
\hline Suillellus luridus (7) 2017 & Liujie, Yuxi [10] & $2.6 \pm 0.0$ & $1.1 \pm 0.0$ & 1.9 & 2.4 \\
\hline Suillus bovinus (8) 2017 & Hongta, Yuxi [24] & $0.4 \pm 0.0$ & $0.07 \pm 0.01$ & 0.30 & 5.7 \\
\hline Sutorius magnificus (19) 2017 & Midu, Dali [8] & $4.3 \pm 0.3$ & $1.8 \pm 0.0$ & 3.0 & 2.4 \\
\hline Sutorius magnificus (6) 2017 & Tadian, Yuxi [5] & $4.1 \pm 0.0$ & $2.8 \pm 0.1$ & 3.4 & 2.3 \\
\hline Sutorius magnificus (6) 2017 & Liujie, Yuxi [10] & $2.0 \pm 0.0$ & $1.6 \pm 0.1$ & 1.8 & 1.2 \\
\hline Thelephora ganbajun (1) 2013 & Cangyuan, Lincang [25] & WD & WD & $0.13 \pm 0.00$ & WD \\
\hline Thelephora ganbajun (1) 2014 & Jiuxi, Yuxi [15] & WD & WD & $0.13 \pm 0.02$ & WD \\
\hline Tylopilus chromapes (32) 2017 & Tadian, Yuxi [5] & $3.3 \pm 0.0$ & $2.0 \pm 0.0$ & 2.7 & 1.6 \\
\hline Tylopilus felleus (5) 2017 & Donggua, Chuxiong [7] & $7.2 \pm 0.4$ & $3.1 \pm 0.0$ & 5.1 & 2.3 \\
\hline Tyromyces albidus Donk. (1) 2014 & Ailao Mountain, Yuxi [26] & WD & WD & $0.024 \pm 0.01$ & WD \\
\hline Tyromyces albidus Donk. (1) 2014 & Jiuxi, Yuxi [15] & WD & WD & $0.046 \pm 0.001$ & WD \\
\hline Xerocomus sp. (8) 2017 & Luohe, Yuxi [9] & $6.8 \pm 0.3$ & $5.1 \pm 0.1$ & 6.1 & 1.3 \\
\hline
\end{tabular}

$W D$ without data

*Number of fruiting bodies in a composite sample

/Number of fruiting bodies unknown

${ }^{\text {a }}$ Cultivated

\# ID of a site (see Fig. 1) 


\section{Results}

\section{$\mathrm{Hg}$ in forest topsoil}

The Hg concentration in forest topsoil at different depths from three sites spatially scattered across the Yunnan province suggests that, both, geogenic sources corresponding to specific topsoil profiles of $\mathrm{Hg}$ in Dulong and Changning, and an anthropogenic influence in Changning and Zhenyuan, seem possible (Fig. 2). A substantial enrichment of $\mathrm{Hg}$ in the top 0$6.0-\mathrm{cm}$ layer and especially in the organic $0-4.0-\mathrm{cm}$ layer (Hg contents from 0.060 to $0.11 \mathrm{mg} \mathrm{kg}^{-1}$ dry weight (dw) in segments) of forest topsoil near the Zhenyuan village in Mt. Ailao region is clear.

Mercury contents in segments of the mineral horizon in the Zhenyuan site were in the range 0.027 to $0.050 \mathrm{mg} \mathrm{kg}^{-1} \mathrm{dw}$ in 5.0- to 12-cm layer, which is around a half of the results for Changning ( 0.10 to $0.12 \mathrm{mg} \mathrm{kg}^{-1} \mathrm{dw}$ in section of 1.0 to $25 \mathrm{~cm})$ and Dulong $\left(0.10 \mathrm{mg} \mathrm{kg}^{-1} \mathrm{dw}\right.$ in section of 1.0 to $10 \mathrm{~cm}$ ). A geogenic source of $\mathrm{Hg}$ at the Changning and Dulong sites seems clear (Figs. 1 and 2), and isotopic fingerprints could further aid the identification of sites with $\mathrm{Hg}$ geological anomalies where wild mushrooms are traditionally harvested in Yunnan. A weak organic layer of topsoil from the forested area near the Changning site was relatively thin $(0$ $1.0 \mathrm{~cm}$ ) and was almost absent in the profile from the Dulong site.

\section{$\mathrm{Hg}$ in fungi}

In this study, species of wood-decaying macromycetes growing on the trunks of living or dead trees included species such as Amauroderma bataanense, Amauroderma guangxiense, Amauroderma niger, $F$. rufolaccatus, F. pinicola, $F$. ulmaria, G. applanatum, G. capense, G. japonicum, G. kunmingense, G. lingzhi, G. lucidum, G. luteomarginatum, G. philippii, G. ramosissimum, G. sinense, G. tsugae, I. resinosum, and $L$. edodes. The stipes contained $\mathrm{Hg}$ in the range from $0.015 \pm 0.001$ in $L$. edodes to $0.095 \pm 0.003 \mathrm{mg} \mathrm{kg}^{-1} \mathrm{dw}$ in G. luteomarginatum, while cap concentrations ranged from $0.015 \pm 0.001$ in $L$. edodes to $0.18 \pm 0.00 \mathrm{mg} \mathrm{kg}^{-1} \mathrm{dw}$ in G. luteomarginatum, and the whole fruiting bodies, from 0.015 in $L$. edodes to $0.19 \pm$ $0.01 \mathrm{mg} \mathrm{kg}^{-1} \mathrm{dw}$ in G. capense (Table 1). The maximum concentration of $\mathrm{Hg}$ between the polypore species in this study was $0.24 \mathrm{mg} \mathrm{kg}^{-1} \mathrm{dw}$ in a sample of $A$. niger. Data for these wood-decaying fungi usually showed higher content of $\mathrm{Hg}$ in caps than stipes. The cap to stipe concentration quotient $\left(Q_{\mathrm{C} / \mathrm{S}}\right)$ was in the range 0.98 to 2.1 (median 1.4) for G. lingzhi, from 1.1 to 1.9 for other Ganoderma mushrooms, from 1.0 to 1.3 for L. edodes, and 1.6 for A. bataanense (Table 1).

In addition to wood-decaying wild mushrooms, the other types investigated in this study were the ectomycorrhizal species such as B. bicolor, B. bainiugan, B. speciosus, B. regius, B. subsplendidus, C. calopus, C. ventricosum, L. extremiorientale, $N$. brunneissimus, R. griseus, $R$. ornatipes, $R$. sinicus, S. luridus, S. magnificus, T. chromapes, T. felleus, and Xerocomus sp., which all showed $\mathrm{Hg}$ concentrations from one to three orders of magnitude higher (Table 1) than the wood-decaying species studied. The only non-wood-decaying saprobic species studied was A. blazei, which showed $\mathrm{Hg}$ in a concentration similar to those determined in the wood-decaying species.

Some of the highest $\mathrm{Hg}$ concentrations found were in species such as $B$. bicolor (up to $8.6 \pm 0.4 \mathrm{mg} \mathrm{kg}^{-1} \mathrm{dw}$ ), B. bainiugan (up to $14 \pm 0 \mathrm{mg} \mathrm{kg}^{-1} \mathrm{dw}$ ), B. speciosus (up to $6.4 \pm 0.1 \mathrm{mg} \mathrm{kg}^{-1} \mathrm{dw}$ ), B. regius (up to $4.6 \pm 0.1 \mathrm{mg} \mathrm{kg}^{-1} \mathrm{dw}$ ), B. subsplendidus (up to $12 \pm 1 \mathrm{mg} \mathrm{kg}^{-1} \mathrm{dw}$ ), C. calopus (up to $9.8 \pm 0.3 \mathrm{mg} \mathrm{kg}^{-1} \mathrm{dw}$ ), S. magnificus (up to $4.3 \pm 0.3 \mathrm{mg} \mathrm{kg}^{-1}$ $\mathrm{dw}$ ), C. ventricosum (up to $5.5 \pm 0.0 \mathrm{mg} \mathrm{kg}^{-1} \mathrm{dw}$ ), L. extremiorientale (up to $6.1 \pm 0.5 \mathrm{mg} \mathrm{kg}^{-1} \mathrm{dw}$ ), T. felleus (up to $7.2 \pm 0.4 \mathrm{mg} \mathrm{kg}^{-1} \mathrm{dw}$ ), or Xerocomus sp. (up to $6.8 \pm$ $0.3 \mathrm{mg} \mathrm{kg}^{-1} \mathrm{dw}$ ), while usually stipes showed from 1.2- to 5.7-fold (Table 1) lower than the caps.

The quality of the medicinal mushrooms in this study in view of contamination with $\mathrm{Hg}$ presents a complex picture both due to the kind of species collected and the difference in the pattern of contamination between them. The medicinal species including all the "hard" type polypore fungi, L. edodes and T. ganbajun, presented a lower risk as far as the possible toxic effects of total $\mathrm{Hg}$ could be considered (Table 1). As mentioned, $\mathrm{Hg}$ concentrations in these mushrooms were up to $0.24 \mathrm{mg} \mathrm{kg}^{-1} \mathrm{dw}$, as seen in A. niger. Hence, consumer exposure to $\mathrm{Hg}$ contained in the hypothetical medicinal derivatives of these mushrooms was investigated alone for the "hard" species including $L$. edodes and T. ganbajun using a maximum value of $0.24 \mathrm{mg} \mathrm{kg}^{-1} \mathrm{dw}$ and separately for other soft flesh mushrooms-largely from the Boletaceae family, using a maximum value of up to $10 \mathrm{mg} \mathrm{kg}^{-1} \mathrm{dw}$ for a whole fruiting body of $B$. bainiugan from the Donggua site in the Chuxiong region of Yunnan (Table 1).

\section{Estimated intake of $\mathrm{Hg}$}

The exposure estimations in this study assumed an intake biomass of $3 \times 0.5 \mathrm{~g}$ of capsulated dried product - both of "hard" and "soft" flesh type mushrooms per capita daily over a week, and from 100 to $300 \mathrm{~g}$ (maximal $500 \mathrm{~g}$ ) in a meal (Boletaceae family species). The intakes also assumed the maximal Hg concentrations for "hard" and "soft" flesh type mushrooms, respectively, for an adult Asian individual $(60 \mathrm{~kg}$ body mass, bm). The "worst case" estimates showed intake of $\mathrm{Hg}$ from $0.006 \mu \mathrm{g} \mathrm{kg}^{-1} \mathrm{bm}$ ("hard" type polypore) and $0.25 \mu \mathrm{g} \mathrm{kg}^{-1} \mathrm{bm}$ ("soft" flesh Boletaceae) on a daily basis for capsulated products, and 17,50 , and $83 \mu \mathrm{g} \mathrm{kg}^{-1} \mathrm{bm}$ in the case of meals made of Boletaceae mushrooms, respectively. 
Hence, on a weekly basis, intake could reach $0.042,1.7,120$, 350 , and $580 \mu \mathrm{g} \mathrm{kg}^{-1} \mathrm{bm}$.

\section{Discussion}

\section{Topsoil}

In this study, the site of Zhenyuan represents a sparsely inhabited rural area with small farms scattered around and the region is remote from the urbanized and industrialized sites/centers of China. A recent study of $\mathrm{Hg}$ concentration and isotopic signatures in the forest topsoil (2016) and litter fall (2017) samples collected from the windward (1250$2400 \mathrm{~m}$ a.s.1.) and leeward slopes of Mt. Ailao (850-2400 m a.s.l) suggested that contamination of topsoil $(0-10 \mathrm{~cm}$ layer $)$ is largely from litter fall input, which relates well with the observation in this study (Fig. 2) (Fu et al. 2019).

In China soil, with $\mathrm{Hg}$ concentration $\leq 0.150 \mathrm{mg} \mathrm{kg}^{-1} \mathrm{dw}$ could be qualified as grade I (uncontaminated) according to the Chinese Environmental Quality Standard for Soils (Shi et al. 2013). Nevertheless, a regional and local enrichment in $\mathrm{Hg}$ of forest topsoils in Yunnan suggests a strong contribution from the Hg background in bedrock (Nie et al. 2018).

Previous studies that analyzed soils collected underneath mushrooms sampled from the forests of Yunnan have found that the concentration of $\mathrm{Hg}$ in the top layer $(0-10 \mathrm{~cm})$ is elevated when compared with forest topsoils from the regions of southern and northern Europe. This type of soil from Croatia and northern parts of Poland typically shows $\mathrm{Hg}$ at concentration well below $0.05 \mathrm{mg} \mathrm{kg}^{-1} \mathrm{dw}$ (Falandysz et al. 2015b; Širić and Falandysz 2020). For example, in China, the topsoils from 44 sites sampled in parallel with the Boletaceae family mushrooms from rural and anthropogenically unpolluted regions showed $\mathrm{Hg}$ in the range 0.034 to $3.4 \mathrm{mg} \mathrm{kg}^{-1}$ $\mathrm{dw}$, and from 12 sites where Leccinum mushrooms were collected, in the range from 0.065 to $0.58 \mathrm{mg} \mathrm{kg}^{-1} \mathrm{dw}$ (Falandysz et al. 2015a, b). In topsoil underneath Xerocomus spp. in Yunnan, the $\mathrm{Hg}$ concentration was in the range 0.21 to $0.49 \mathrm{mg} \mathrm{kg}^{-1} \mathrm{dw}(n=4)$ and topsoil underneath Macrocybe gigantea (Pu'er prefecture in Yunnan) was in the range 0.075 to $0.24 \mathrm{mg} \mathrm{kg}^{-1} \mathrm{dw}(n=7)$ (Kojta et al. 2015; Wiejak et al. 2014).

\section{Fungi}

Wood-decaying polypore mushrooms and L. edodes have a special position in traditional herbal medicine in China, and species examined in this study showed low contamination with $\mathrm{Hg}$. As far as possible toxic effects were concerned, the $\mathrm{Hg}$ concentrations observed in the studied Ganoderma and other wood-decaying mushrooms would imply a relatively low level of health concern.
Nowadays, formulations made for medicinal and gourmet mushrooms or cultivated medicinal and edible species can be bio-fortified with certain elements, e.g., selenized or lithiumized (often a composite of several species) and sold in capsules as a food supplement as a mix of dried and powdered products. It would be useful to know whether the manner of preparation (processing) of the medicinal mushrooms during formulation can have an effect on the $\mathrm{Hg}$ (and other elements) content of the final products but no data could be found in the available literature.

Preparation processes involve water or alcohol (ethanol) extracts or a composite of alcohol and water extracts of sliced, dried, or fresh, polypore mushrooms (reishi mushrooms, e.g., G. lucidum) from cold maceration or making a decoction by simmering with water at different time intervals (up to several weeks) and following a specific recipe. Therefore, a liquid formula obtained can be a simple macerate, tincture, decoct, or a composite elixir. A product can also be in a form of a powder prepared from a decoct after evaporation of the water.

Traditional culinary practices of preparing mushrooms such as stir frying in oil or braising do not decrease, while can increase contents, e.g., $\mathrm{Hg}$, radiocaesium $\left({ }^{137} \mathrm{Cs}\right)$ and natural ${ }^{40} \mathrm{~K}$ (hence also $\mathrm{K}$ ) in mushroom meals, when related to the contents in the fresh mushrooms based on the whole (wet) weight (Falandysz et al. 2019a, b, 2020b, c). Hot water alone or with a chelating agent will extract a proportion of the mineral constituents including $\mathrm{Hg}$ from fungal flesh (Drewnowska et al. 2017a, b; Stijve 1994; Svoboda et al. 2002). For example, traditional blanching using only water and boiling removes some $\mathrm{Hg}$ together with water soluble compounds and colloids from fresh fruiting bodies, e.g., Cantharellus cibarius and Amanita fulva mushrooms (Falandysz and Drewnowska 2017), which implies that not only water extracts but also organic solvent extracts $(\mathrm{MeHg}$ is also lipophilic compound) can transfer $\mathrm{Hg}$ compounds from a mushroom substrate to formulations.

It must be pointed out that these reported values of $\mathrm{Hg}$ are within the ranges noticed in several other species of edible mushrooms from the regions of Yunnan. The maximum concentration recorded was in a composite sample of fruiting bodies of the B. bainiugan (called B. edulis in Yunnan before a molecular phylogenetic recognition as a new genus in the family of Boletaceae; B. edulis is absent in Yunnan) with $22 \mathrm{mg} \mathrm{kg}^{-1} \mathrm{dw}$ in the caps, $8.4 \mathrm{mg} \mathrm{kg}^{-1} \mathrm{dw}$ in the stipes (Falandysz et al. 2015b).

There is no data available on the extraction efficiency of $\mathrm{Hg}$ (all chemical forms of $\mathrm{Hg}$ ) during the production of dried pure (medicinal grade) extracts from any polypore mushroom. A 15-min blanching of fresh mushrooms in tap water has limited effect on the release (loss) of $\mathrm{Hg}$ from fruiting bodies on a dry weight basis (Falandysz and Drewnowska 2015, 2017). Stir frying in deep oil can cause the increase in $\mathrm{Hg}$ concentration in 
fried mushrooms (Falandysz et al. 2019a, b) and braising the effect of braising was to increase the average total $\mathrm{Hg}(\mathrm{THg})$ and $\mathrm{MeHg}$ contents in fresh mushroom meals by around $50 \%$ respectively, but a reduction of around $40 \%$ respectively was seen on a dry weight basis (submitted). The increase in $\mathrm{Hg}$ concentration in fried or braised mushrooms can be explained by the partial decline in moisture content during processing and the resulting shrinkage of the fungal matrix accompanied by the preferential retention of a portion of $\mathrm{Hg}$.

However, the polypore species used for medicines are first dried and pulverized and depending on the recipe can then be, e.g., macerated for a long period of time with ethanol (vodka) and water and finally, extracted, dried, and capsuled. Such a process of prolonged maceration and extraction could be more effective at removing $\mathrm{Hg}$ than blanching for a short period with hot or boiling tap water. Hence, due to the lack of data on $\mathrm{Hg}$ in dried pure extracts from polypore fungi that can be purchased in retail outlets, assessments of $\mathrm{Hg}$ intake could make the assumption that $\mathrm{Hg}$ concentration in a formulation is the same as that in the original substrate based on dry biomass. As mentioned, some fungal supplements are composed only of dried and powdered mushrooms bio-fortified with Se or $\mathrm{Li}$, where the content of the bio-element is around 10-fold higher than in the fresh substrate. A gelatine capsule is filled with $500 \mathrm{mg}$ of fungal formulation regardless of the size of the capsule. On the other hand, the quantity of cooked edible mushrooms in a single meal is estimated at 100 to $300 \mathrm{~g}$ and occasionally above $500 \mathrm{~g}$. The frequency of eating wild mushrooms and hence also the annual rate of consumption varies between people, countries, and regions and availability during a particular year, and the maximum quantity reported was $20 \mathrm{~kg}$ fresh biomass in Yunnan of China and up to $26 \mathrm{~kg}$ in the UK (Barnett et al. 2001; Zhang et al. 2010). Because of their particular diet, vegans and vegetarians can be characterized by a higher rate of mushrooms as also can Asian people, where wild mushrooms form a popular meal although there are some individuals who cannot eat them. Mushrooms are a vitamin Drich source in the diet of vegetarians and vegans (Kim et al. 2018), and are several dozen recipes for mushroom dishes intended for vegetarians and vegans.

Wood-decaying fungi, both of hard (polypore) and soft (L. edodes) types, were poorer accumulators of $\mathrm{Hg}$ compared with the ectomycorrhizal and saprobic species in this (Table 1) and other studies (Dryżałowska and Falandysz 2014; Melgar et al. 2009; Saba et al. 2016a, b). Comparatively, hard (polypore) species of wood-decaying macromycetes show lower K, Rb, and Na contents than soft species (Tyler 1982). They are also relatively low in other metallic elements and metalloids including Cd (Siwulski et al. 2017), but they seem to be useful as indicators of atmospheric pollution by $\mathrm{Pb}$ (Gabriel et al. 1997; Tyler 1982).

\section{Hg exposure assessment}

The estimated maximal doses derived from data for the Boletaceae mushrooms exceed the published daily reference dose (RfD) for $\mathrm{Hg}$ at $0.3 \mu \mathrm{g} \mathrm{kg}^{-1}$ bm or the provisionally tolerable weekly intake (PTWI) that is $3.4 \mu \mathrm{g} \mathrm{kg}^{-1} \mathrm{bm}$ for a $60 \mathrm{~kg} \mathrm{bm}$ individual (derived from the original value of $4.0 \mu \mathrm{g} \mathrm{kg}^{-1} \mathrm{bm}$ for a $70 \mathrm{~kg} \mathrm{bm}$ individual) (WHO 2011).

The natural antagonists of $\mathrm{Hg}$ are selenium (Se) and sulfur (S), with Se being a specific antagonist for $\mathrm{MeHg}$ (Ralston and Raymond 2018). Neither Se and S were determined in this study, although they can play a role in the protection of a consumer from the excess $\mathrm{Hg}$ (and $\mathrm{MeHg}$ ) contained in wild mushrooms, e.g., in mushrooms of some genera from the family Boletaceae rich in Se (Falandysz 2013; Kavčič et al. 2019; Nasr et al. 2012). There is no doubt that mushrooms from certain regions of the world are foods that can be elevated in $\mathrm{Hg}$ because of species physiology and in parallel with $\mathrm{Hg}$ geological anomalies in background regions (without substantial local pollution), and in a part due to global fallout (Falandysz et al. 2015b; Melgar et al. 2009; Ostos et al. 2015). Mushrooms can also efficiently pick up $\mathrm{Hg}$ from grounds contaminated with this element because of cinnabar mining or from other industrial sources (Árvay et al. 2014; Falandysz 2016; Kavčič et al. 2019).

A recent study showed high concentrations of Se in mushrooms from Yunnan such as B. bicolor, B. bainiugan, B. roseoflavus, $R$. griseus, $R$. extremiorientalis, and $S$. magnificus. Concentrations ranged from 5.2 to $56 \mathrm{mg} \mathrm{kg}^{-1} \mathrm{dw}$, with stir-fried mushroom meals in the range from $4.6 \mathrm{mg} \mathrm{kg}^{-1} \mathrm{dw}$ for $R$. extremiorientalis to $33 \mathrm{mg} \mathrm{kg}^{-1}$ $\mathrm{dw}$ for B. roseoflavus (Falandysz et al. 2020b). In the evolutionary process of minerals bio-geo-cycling, $\mathrm{Hg}$ and $\mathrm{Se}$ can interact, and ingested $\mathrm{MeHg}$, which is highly neurotoxic, can interact with Se via selenoenzyme in neuronal cells in the central nervous system causing irreversible inhibition of selenium (Se)-dependent enzymes which are protective of oxidative damage in brain cells. The occurrence of $\mathrm{Se}$ in molar excess of $\mathrm{MeHg}$ counters this interruption of selenoenzyme activities (Ralston and Raymond 2018). The contents of Se both in some mushrooms from the Boletaceae family and in stir-fried meals made from them largely exceed (on a molar basis) the co-occurring $\mathrm{Hg}$ concentrations (Falandysz et al. 2020b). Thus, an excess of bioaccessible Se co-occurrence may not create susceptibility to the neurotoxic effect from the different forms of $\mathrm{Hg}$ in these mushrooms for exposed humans. Curiously, the sclerotia of medicinal fungus Wolfiporia cocos (Schwein.) Ryvarden \& Gilb., from Yunnan, contained $\mathrm{Hg}$ concentrations (molar basis) that exceeded Se (Falandysz et al. 2020a). The incidence of polymetallic belts, $\mathrm{Hg}$ geochemical anomalies, substantially elevated concentrations of $\mathrm{Hg}$ in mushroom meals combined with relatively high intake rates in Yunnan, calls for further studies on this topic. 
"Hard" type medicinal polypore fungi in Yunnan province in China showed relatively low contamination with $\mathrm{Hg}$ while "soft" types which are used both as edible and medicinal fungi (e.g., from the family Boletaceae) showed from one to three orders of magnitude higher concentrations which implies substantial contamination. The $\mathrm{Hg}$ concentrations in forest topsoil layers showed localized influences both from geogenic background and airborne deposition (probably largely from litter fall). The estimated intake of $\mathrm{Hg}$ from medicinal fungi of Yunnan based on data for a raw substrate can be considered low in the case of polypore species, but could be substantial in the case of "soft" type fungi from the family Boletaceae. There is a huge gap in knowledge on possible effect of the technologies used in processing of fungi on the $\mathrm{Hg}$ content in medicinal formulations.

Authors' contributions JF: Conception and design of study, formal analysis, resources, writing-original draft preparation, and editing; MM and MS: resources, formal analysis, and data curation; JZ: contributed to the study conception, data curation, and visualization preparation; YW and TL: contributed to the study conception, resources, and investigation. All authors read and approved the manuscript.

Funding This study in part was financially supported by the National Science Centre under grant no. UMO-2016/23/N/NZ9/02746 and the National Natural Science Foundation of China under grant no. 31860584.

\section{Compliance with ethical standards}

Conflict of interest The authors declare that they have no conflict of interest.

Ethical statement This article does not contain any studies with human participants or animals performed by any of the authors.

Open Access This article is licensed under a Creative Commons Attribution 4.0 International License, which permits use, sharing, adaptation, distribution and reproduction in any medium or format, as long as you give appropriate credit to the original author(s) and the source, provide a link to the Creative Commons licence, and indicate if changes were made. The images or other third party material in this article are included in the article's Creative Commons licence, unless indicated otherwise in a credit line to the material. If material is not included in the article's Creative Commons licence and your intended use is not permitted by statutory regulation or exceeds the permitted use, you will need to obtain permission directly from the copyright holder. To view a copy of this licence, visit http://creativecommons.org/licenses/by/4.0/.

\section{References}

Ariya PA, Amyot M, Dastoor A, Deeds D, Feinberg A, Kos G, Poulain A, Ryjkov A, Semeniuk K, Subir M, Toyota K (2015) Mercury physicochemical and biogeochemical transformation in the atmosphere and at atmospheric interfaces: a review and future directions. Chem Rev 115:3760-3802

Árvay J, Tomáša J, Hauptvogl M, Kopernická M, Kováčik A, Bajčan D, Massányi P (2014) Contamination of wild-grown edible mushrooms by heavy metals in a former mercury-mining area. J Environ Sci Health Part B - Pest Food Contam Agric Waste 49:815-827

Barnett CL, Beresford NA, Frankland JC, Self PL, Howard BJ, Marriott JVR (2001) Radiocaesium intake in Great Britain as a consequence of the consumption of wild fungi. Mycologist 15:98-104

Bhatt RP, Singh U, Uniyal P (2018) Healing mushrooms of Uttarakhand Himalaya, India. Curr Res Environ Appl Mycol 8:1-23. https://doi. org/10.5943/cream/8/1/1

Bressa G, Cima L, Costa P (1988) Bioaccumulation of Hg in the mushroom Pleurotus ostreatus. Ecotoxicol Environ Saf 16:85-89

Chen L, Liang S, Liu M, Yi Y, Mi Z, Zhang Y, Li Y, Qi J, Meng J, Tang X, Zhang H, Tong Y, Zhang W, Wang X, Shu J, Yang Z (2019) Trans-provincial health impacts of atmospheric mercury emissions in China. Nat Commun 10:1484. https://doi.org/10.1038/s41467019-09080-6

Crane S, Dighton J, Barkay T (2010) Growth responses to and accumulation of mercury by ectomycorrhizal fungi. Fungal Biol 114:873880

Demers JD, Driscoll CT, Fahey TJ, Yavitt JB (2007) Mercury cycling in litter and soil in different forest types in the Adirondack region, New York, USA. Ecol Appl 17:1341-1351

Drewnowska M, Falandysz J, Chudzińska M, Hanć A, Saba M, Barałkiewicz D (2017a) Leaching of arsenic and sixteen metallic elements from Amanita fulva mushrooms after food processing. LWT Food Sci Technol 84:861-866

Drewnowska M, Hanć A, Barałkiewicz D, Falandysz J (2017b) Pickling of chanterelle Cantharellus cibarius mushrooms highly reduce cadmium contamination. Environ Sci Pollut Res 23:21733-22173

Dryżałowska A, Falandysz J (2014) Bioconcentration of mercury by mushroom Xerocomus chrysenteron from the spatially distant locations: levels, intake and safety. Ecotoxicol Environ Saf 107:97-102

Falandysz J (2002) Mercury in mushrooms and soil of the Tarnobrzeska Plain, south-eastern Poland. J Environ Sci Health Part A - Toxic/ Hazard Sub Environ Eng 37:343-352

Falandysz J (2013) Review: on published data and methods for selenium in mushrooms. Food Chem 138:242-250

Falandysz J (2016) Mercury bio-extraction by fungus Coprinus comatus: a possible bioindicator and mycoremediator of polluted soils? Environ Sci Pollut Res 23:7444-7451

Falandysz J, Drewnowska M (2015) Distribution of mercury in Amanita fulva (Schaeff.) Secr. mushrooms: accumulation, loss in cooking and dietary intake. Ecotoxicol Environ Saf 115:49-54

Falandysz J, Drewnowska M (2017) Cooking can decrease mercury contamination of a mushroom meal: Cantharellus cibarius and Amanita fulva. Environ Sci Pollut Res 24:13352-13357

Falandysz J, Frankowska A, Mazur A (2007) Mercury and its bioconcentration factors in King Bolete (Boletus edulis). Bull Fr J Environ Sci Heath Part A - Toxic/Hazard Sub Environ Eng 42: 2089-2095

Falandysz J, Dryżałowska A, Saba M, Wang J, Zhang D (2014) Mercury in the fairy-ring of Gymnopus erythropus (Pers.) and Marasmius dryophilus (Bull.) P. Karst. mushrooms from the Gongga Mountain, Eastern Tibetan Plateau. Ecotoxicol Environ Saf 104: $18-22$

Falandysz J, Zhang J, Wang Y, Krasińska G, Kojta A, Saba M, Shen T, Li T, Liu H (2015a) Evaluation of the mercury contamination in mushrooms of genus Leccinum from two different regions of the world: accumulation, distribution and probable dietary intake. Sci Total Environ 537:470-478

Falandysz J, Zhang J, Wang Y, Saba M, Krasińska G, Wiejak A, Li T (2015b) Evaluation of the mercury contamination in Fungi Boletus species from latosols, lateritic red earths, and red and yellow earths in the Circum-Pacific Mercuriferous Belt of southwestern China. PLoSONE 10(11):e0143608. https://doi.org/10.1371/journal.pone. 0143608 
Falandysz J, Dryżałowska A, Zhang J, Wang Y (2019a) Mercury in raw mushrooms and mushrooms stir-fried in deep oil. J Food Compos Anal 82:103239

Falandysz J, Zhang J, Mędyk M, Zhang X (2019b) Mercury in stir-fried and raw mushrooms from the Boletaceae family from the geochemically anomalous region in the Midu county, China. Food Control 102:17-21

Falandysz J, Saba M, Zhang J, Hanć A (2020a) Occurrence, distribution and estimated intake of mercury and selenium from sclerotia of the medicinal fungus Wolfiporia cocos from China. Chemosphere 247: 125928

Falandysz J, Mędyk M, Hanć A, Komorowicz I, Zhang J, Barałkiewicz D, Zhang X (2020b) Selen i niektóre inne biopierwiastki w grzybach z rodziny Borowikowate i posiłkach z grzybów w Yunnanie. XIII Konferencja "Analiza Specjacyjna - Możliwości i Kierunki Rozwoju”. Uniwersytet Adama Mickiewicza, Poznań, 5-6 marca 2020 roku

Falandysz J, Wang Y, Saniewski M, Fernandes AR (2020c) 137Caesium, 40Potassium and potassium in raw and deep-oil stir-fried mushroom meals from Yunnan in China. J Food Compost Anal 91:103538

Falandysz J, Shi J, Monti C (2020d) Environmental cycling and fate of mercury: 2020. Chemosphere 261:127766

Fernandes A, Falandysz J, Širić I (2020) The toxic reach of mercury and its compounds in human and animal food webs. Chemosphere 261: 127765

Fu X, Zhang H, Liu C, Zhang H, Lin C-J, Feng X (2019) Significant Seasonal Variations in Isotopic Composition of Atmospheric Total Gaseous Mercury at Forest Sites in China Caused by Vegetation and Mercury Sources. Environ Sci Technol 53(23):13748-13756

Gabriel J, Baldrian P, Rychlovský P, Krenzelok M (1997) Heavy metal content in wood-decaying fungi collected in Prague and in the National Park Šumava in the Czech Republic. Bull Environ Contam Toxicol 59:595-602

Gründemann C, Reinhardt JK, Lindequist U (2020) European medicinal mushrooms: do they have potential for modern medicine? -an update. Phytomedicine 66:153131. https://doi.org/10.1016/j.phymed. 2019.153131

Grzywnowicz K (2001) Medicinal mushrooms in Polish folk medicine. Int J Med Mushrooms 3:154

Grzywnowicz K (2007) Some data from the ethnomycology of preSlavonic and Slavonic tribes on polish territory. Int J Med Mushrooms 9:261

Gustin M, Lindberg S, Marsik F, Casimir A, Ebinghaus R, Edwards G, Hubble-Fitzgerald C, Kemp R, Kock H, Leonard T, London J, Majewski M, Montecinos C, Owens J, Pilote M, Poissant L, Rasmussen P, Schaedlich F, Schneeberger D, Schroeder W, Sommar J, Turner R, Vette A, Wallschlaeger D, Xiao Z, Zhang H (1999) Nevada STORMS project: measurement of mercury emissions from naturally enriched surfaces. J Geophys Res 104:2183121844

Jarzyńska G, Falandysz J (2011) The determination of mercury in mushrooms by CV-AAS and ICP-AES techniques. J Environ Sci Health Part A - Toxic/Hazard Sub Environ Eng 46:569-573

WHO (2011) Evaluation of certain contaminants in food: seventy-second report of the Joint FAO/WHO Expert Committee on Food Additives. (WHO technical report series ; no. 959). TRS 959JECFA 72

Kavčič M, Petric M, Vogel-Mikuš K (2018) Chemical speciation using high energy resolution PIXE spectroscopy in the tender X-ray range. Nucl Instr Meth Phys Res B 417:65-69

Kavčič A, Mikuš K, Debeljak M, Teun van Elteren J, Arčon I, Kodre A, Kump P, Karydas AG, Migliori A, Czyżycki M, Vogel-Mikuš K (2019) Localization, ligand environment, bioavailability and toxicity of mercury in Boletus spp. and Scutiger pes-caprae mushrooms. Ecotoxicol Environ Saf 184:109623
Kijewski P (1989) Fluor, arsen i rtęć w polimetalicznym złożu miedzi monokliny przedsudeckiej. Fizykochem Problemy Mineralurgii 21: 211-219

Kim S, Fenech MF, Kim P-J (2018) Nutritionally recommended food for semi- to strict vegetarian diets based on large-scale nutrient composition data. Sci Rep 8:4344. https://doi.org/10.1038/s41598-01822691-1

Kojta AK, Wang Y, Zhang J, Li T, Saba M, Falandysz J (2015) Mercury contamination of fungi genus Xerocomus in the Yunnan Province in China and the region of Europe. J Environ Sci Health Part A - Toxic/ Hazard Sub Environ Eng 50:1342-1350

Li L, Wang B (2008) Geochemical characteristics of As and Cd in soils of Yunnan province. Geophys Geochem Explor 32:497-501

Melgar MJ, Alonso J, Garcia MÁ (2009) Mercury in edible mushrooms and soil. Bioconcentration factors and toxicological risk. Sci Total Environ 407:5328-5334

Money NP (2016) Are mushrooms medicinal? Fungal Biol 120:449-453

Nasr N, Arp PA (2011) Hg concentrations and accumulations in fungal fruiting bodies, as influenced by forest soil substrates and moss carpets. Appl Geochem 26:1905-1917

Nasr N, Malloch DW, Arp PA (2012) Quantifying Hg within ectomycorrhizal fruiting bodies, from emergence to senescence. Fungal Biol 116:1163-1177

Nie L, Liu X, Wang X, Liu H, Wang W (2018) Interpretation of regionalscale distribution of high $\mathrm{Hg}$ in soils of karst area in southwest China. Geochem: Explor Environ Anal 19:289-298

Nnorom IC, Jarzyńska G, Drewnowska M, Dryżałowska A, Kojta A, Pankavec S, Falandysz J (2013) Major and trace elements in sclerotium of Pleurotus tuber-regium (Ósu) mushroom -dietary intake and risk in southeastern Nigeria. J Food Compos Anal 29:73-81

Nnorom IC, Eze SO, Ukaogo PO (2019) Mineral contents of three wildgrown edible mushrooms collected from forests of south eastern Nigeria: An evaluation of bioaccumulation potentials and dietary intake risks. Sci Afr:e00163

Ostos C, Perez-Rodriguez F, Arroyo BM, Moreno-Rojas R (2015) Study of mercury content in wild edible mushrooms and its contribution to the provisional tolerable weekly intake in Spain. J Food Compos Anal 37:136-142

Ralston NVC, Raymond LJ (2018) Mercury's neurotoxicity is characterized by its disruption of selenium biochemistry. Biochim Biophys Acta, Gen Subj 1862:2405-2416

Saba M, Nnorom IC, Falandysz J (2016a) Mercury bioaccumulation by Suillus bovinus mushroom and probable dietary intake with the mushroom meal. Environ Sci Pollut Res 23:14549-14559

Saba M, Falandysz J, Nnorom IC (2016b) Evaluation of vulnerability of Suillus variegatus and Suillus granulatus mushrooms' to sequester mercury in fruiting bodies. J Environ Sci Health Part B - Pest Food Contam Agric Waste 51:540-545

Saba M, Falandysz J, Nnorom IC (2016c) Accumulation and distribution of mercury in fruiting bodies by fungus Suillus luteus foraged in Poland, Belarus and Sweden. Environ Sci Pollut Res 23:2749-2757

Santiago FH, Moreno JP, Cázares BX, Suárez JJA, Trejo EO, Montes de Oca GM, Aguilar ID (2016) Traditional knowledge and use of wild mushrooms by Mixtecs or Ñuu savi, the people of the rain, from southeastern Mexico. J Ethnobiol Ethnomed 12:35. https://doi.org/ 10.1186/s13002-016-0108-9

Shi J, Meng M, Shao M, Zhang Z, Zhang Q, Jiang G (2013) Spatial distribution of mercury in topsoil from five regions of China. Environ Sci Pollut Res 20:1756-1761

Širić I, Falandysz J (2020) Contamination, bioconcentration and distribution of mercury in Tricholoma spp. mushrooms from Southern and Northern regions of Europe. Chemosphere 251:126614

Siwulski M, Rzymski P, Niedzielski P, Budka A, Gąsecka M, Kalač P, Jasińska A, Budzyńska S, Kozak L, Mleczek M (2017) Comparison of multielemental composition of Polish and Chinese mushrooms (Ganoderma spp.). Eur Food Res Technol 243:1555-1566 
Stijve T (1994) Extraction of radiocesium from contaminated mushrooms. Observ Mycol (Bull l'Observ Mycol) 6:2-9

Stijve T, Roschnik R (1974) Mercury and methyl mercury content of different species of fungi. Trav Chim Aliment Hyg 65:209-220

Suchara I, Sucharova J (2002) Distribution of sulphur and heavy metals in forest floor humus of the Czech Republic. Water Air Soil Pollut 136: 289-316

Svoboda L, Kalač P, Špička J, Janoušková D (2002) Leaching of cadmium, lead and mercury from fresh and differently preserved edible mushroom, Xerocomus badius, during soaking and boiling. Food Chem 79:41-45

Tyler G (1982) Metal accumulation by wood-decaying fungi. Chemosphere 11:1141-1146

Wang K-P (1944) Mineral resources of China: with special reference to the nonferrous metals. Geogr Rev 34:621-635

Wang Y, Zhang J, Zhao Y, Tao L, Tao S, Li J, Li W, Liu H (2013) Mycology, cultivation, traditional uses, phytochemistry and pharmacology of Wolfiporia cocos (Schwein.) Ryvarden et Gilb.: a review. J Ethnopharmacol 145:265-276

Wasser SP (2010) Medicinal mushrooms science: history, current status, future trends, and unsolved problems. Int J Med Mushrooms:12, 116

Wen X, Chi Q (2007) Geochemical spatial distribution of mercury in China. Geochimica 36:633-637
Wiejak A, Wang Y, Zhang J, Falandysz J (2014) Bioconcentration potential and contamination with mercury of pantropical mushroom Macrocybe gigantea. J Environ Sci Health Part B - Pest Food Contam Agric Waste 49:811-814

Yafetto L (2018) The structure of mycelial cords and rhizomorphs of fungi: a mini-review. Mycosphere 9:984-998. https://doi.org/10. 5943/mycosphere/9/5/3

Yongabi KA (2019) African medicinal mushrooms: source of biopharmaceuticals for the treatment of noncommunicable diseases - a review. In: Agrawal D, Dhanasekaran M (eds) Medicinal mushrooms. Springer, Singapore, pp 335-347

Young Y-H, Chuu J-J, Liu S-H, Lin-Shiau S-Y (2002) Neurotoxic mechanism of cinnabar and mercuric sulfide on the vestibulo-ocular reflex system of guinea pigs. Toxicol Sci 67:256-263

Zaidman BZ, Yassin M, Mahajna J, Wasser SP (2005) Medicinal mushroom modulators of molecular targets as cancer therapeutics. Appl Microbiol Biotechnol 67:453-468

Zhang D, Frankowska A, Jarzyńska G, Kojta AK, Drewnowska M, Wydmańska D, Bielawski L, Wang J, Falandysz J (2010) Metals of King Bolete (Boletus edulis) collected at the same site over two years. Afr J Agric Res 5:3050-3055

Publisher's note Springer Nature remains neutral with regard to jurisdictional claims in published maps and institutional affiliations. 